\title{
Perceived Self-Efficacy and its Role in Fostering Pro-Environmental Attitude and Behaviours
}

\author{
Yoong Siew Wai*, Jamil Bojei, Syuhaily Osman and Nor Hashima Hashim
}

\begin{abstract}
Manuscript type: Research paper

Research aims: This study examines perceived self-efficacy and its role in fostering pro-environmental attitude and behaviours.

Design/Methodology/Approach: This study employs a quantitative approach to explain the relationship among the variables. The data of 500 individuals are collected and then analysed through the partial least squared (PLS) approach.

Research findings: Results show that perceived self-efficacy has a positive influence on attitude; it enables individuals to orchestrate their capabilities in pursuing pro-environmental behaviours.

Theoretical contributions/Originality: This study expands on previous literature by adapting lifestyle-centric pro-environmental behaviour and social cognitive theory to identify the factors that motivate pro-environmental behaviours.

Practitioner/Policy implications: This study provides insights for marketers and other policy makers to better understand how perceived self-efficacy impacts the attitude and pro-environmental behaviours of individuals. The results imply that practitioners need to include attitude change campaigns and intervention programmes that can increase self-efficacy so as to encourage individuals to engage in more challenging environmental behaviours.
\end{abstract}

\footnotetext{
* Corresponding author: Yoong Siew Wai is a PhD Student at the Putra Business School, Universiti Putra Malaysia. Email: yoong.phd12@grad.putrabs.edu.my

Jamil Bojei is a Lecturer at the Faculty of Economics and Management, Universiti Putra Malaysia. Email: jamil@upm.edu.my

Syuhaily Osman is a Senior Lecturer at the Human Ecology Faculty, Universiti Putra Malaysia. Email: syuly@upm.edu.my

Nor Hashima Hashim is a Senior Lecturer at the Faculty of Business and Management, Universiti Teknologi Mara (UiTM). Email: norhashima@salam.uitm.edu.my
}

https://doi.org/10.22452/ajba.vol11no2.5 
Research limitation: Since this study focusses on the urban population of Malaysia only, the generalisability of the findings may be restricted. Future studies need to incorporate a larger and more diverse samples.

Keywords: Attitude, Intrinsic Motivation, Perceived Self-efficacy, Pro-environmental Behaviours, Social Cognitive Theory

JEL Classification: M310

\section{Introduction}

The climate changes that are currently occurring around the world is escalating at an alarming rate and this has impacted the ecosystems and threatened human health and safety. In response to these environmental problems, the United Nations (2015) stated that emphasis must be given to sustainable production and consumption practices throughout the world and across all levels of communities, whether public or private. In line with this emphasis, marketers and organisations have begun offering products and services that contain pro-environmental features. Although the production of environmental friendly products and services is encouraging, their take up rate is still low (Department for Business Innovation and Skills, 2013). It appears that the heightened awareness about environmental issues, and the government's initiatives towards nature restoration, and pro-environmental society promotions, have not been influential. The public's attitude towards proenvironmental behaviours is still lukewarm, as reported by the United Nations (2015). It highlighted a low indication of reducing usage or replacing non-environmental friendly products with pro-environmental products and services for sustainable consumption practice.

The findings of existing research (Yazdanpanah \& Forouzani, 2015; Klöckner, 2013; Bauer, Heinrich, \& Schäfer, 2012; Chen et al., 2011) speculate that the purchase intention towards pro-environmental products is influenced by several factors such as attitude, subjective norms and perceived behaviour control and the availability of facilities (Sheth, Sethia, \& Srinivas, 2011; Ramayah, Lee, \& Mohamad, 2010; Omran, Mahmood, Abdul Aziz, \& Robinson, 2009) and information (Davies, Lee, \& Ahonkhai, 2012; Sheth et al., 2011). In addition, current research (Evans, 2011; Sheth et al., 2011) also indicates that there is a spectrum of situational constraints that could affect sustainable behaviours, for instance, cost (Johnstone \& Tan, 2015; Bucic, Harris 
\& Arli, 2012), perceived lower product quality (Johnstone \& Tan, 2015; Baker, Davis, \& Weaver, 2014; Haws, Winterich, \& Naylor, 2014), distrust on environmental claims (Sheth et al., 2011) and limited accessibility (Davies et al., 2012). It was noted by Carrington, Neville and Whitwell (2010) that people's claim of their intention to consume sustainable products exceeds their actual behaviours.

This attitude-behaviour gap (Davies et al., 2012; Papaoikonomou, Valverde \& Ryan, 2012; Phipps et al., 2013) demonstrates the incongruence of cognition and action as a hindrance to achieving and sustaining profound pro-environmental behaviours. When individuals face disparity between cognition (attitudes, beliefs or values) and behaviour, they will experience uncomfortable feelings. Premised on the theory of cognition dissonance, individuals always require consistency in beliefs, attitudes and behaviours. Therefore, if an inequilibrium occurs between these elements, individuals would experience discomfort. This discomfort then 'motivates' them to re-resonate between their beliefs and behaviours so as to attain a balance (Kroesen, Handy, \& Chorus, 2017; Ratliff, Howell, \& Redford, 2017; Johnstone \& Tan, 2015; Juvan \& Dolnicar, 2014). When there is dissonance between attitude and behaviour, individuals are more likely to adapt their attitude and maintain the original state of relationship (Kroesen et al., 2017). Studies (Poortinga, Whitmarsh, \& Suffolk, 2013; Lin \& Chang, 2012; Phipps et al., 2013; Wilcox, Vallen, Block, \& Fitzsimons, 2009) indicate that there are various symptoms such as licensing effects and rebound effects (Akenji, 2014; Lin \& Chang, 2012; Phipps et al., 2013; Miller, Rathouse, Scarles, Holmes, \& Tribe, 2010; Mont \& Plepys, 2008; Briceno \& Stagl, 2006) which signify that pro-environmental behaviours may not be able to withstand in different spatial and temporal dimensions.

Studies (Howe \& Krosnick, 2017; Celik \& Yesilyurt, 2013; Visser, Bizer, \& Krosnick, 2006) also denote that attitude is a significant predictor of behaviour and yet, the state of attitude is contextdependence (Davies et al., 2012; Papaoikonomou et al., 2012; Phipps et al., 2013; Mont \& Plepys, 2008). Although attitude is one's inclination to respond to something positively or negatively, Kroesen et al. (2017) argued that attitude is a state of emotion directed towards a target subject and this can steer an individual's behaviour. Therefore, it is critical to understand the fundamental factors and the mechanisms that shape and sustain a desired attitude and the interaction these factors play in strengthening the relationship between attitude and behaviour. Since the defence mechanism for both attitude and behaviour is to be 
environmental friendly, it is pertinent to identify the determinants for both attitude and behaviour as they are essential for the development of effective pro-environmental interventions. These determinants can be used by individuals in a sustainable and effective manner to instil proenvironmental behaviours across a wide spectrum of activities. Among all, self-efficacy appears to be a strong determining factor.

Perceived self-efficacy is the core in social cognitive theory. The theory states that an individual's collection of perceptions, assessments and regulations will direct his/her behaviour while responding to a complex web of environmental and social systems (Jin, 2013b; Bandura, 1991). Both the individual's attitude and behaviour are context dependent. They acknowledge external factors as the consideration factor for the underpinning behaviours. This study does not examine the individuals' perception with regards to the different social elements that may influence their pro-environmental behaviour adoption. Instead, this study seeks to investigate the resilience of attitude and behaviour. This study also aims to investigate whether perceived selfefficacy is able to provide a strong platform to sustain attitude and behaviour. In this regard, the current study aims to answer the following research questions:

i) Does perceived self-efficacy discourage change in both attitude and pro-environmental behaviours?

ii) Does perceived self-efficacy function as a shield to counterbalance factors such as self-doubt and second thoughts while the individual engages in pro-environmental behaviours?

The organisation of this paper is as follows: Section 2 outlines the theoretical dimension for the three main themes of the study namely: attitude, pro-environmental behaviours and perceived selfefficacy. Section 3 explains the methodology. Section 4 discusses the findings. Section 5 explains the implications of the study and Section 6 concludes.

\section{Literature Review and Hypotheses Development}

\subsection{Lifestyle-Centric Pro-environmental Behaviours}

The notion of pro-environmental behaviour is multidimensional; it is tagged with conflicting objectives thus there is a lack of consensus on its definition (Mont \& Plepys, 2008). Pro-environmental behaviour is 
multifaceted and it touches every point of the supply and demand chain. From the supply perspective, pro-environmental behaviour is relevant as it looks at the effective and efficient production processes and practices, while consumers prefer products which are convenient and affordable.

In order to understand the make-up of an individual who is proenvironment, it is essential to understand the process the individual goes through in acquiring the intention to minimise impact on the environment and to go beyond the point of consumption. Existing research (Shaw, Mcmaster, \& Newholm, 2016; Jagers, Martinsson, \& Matti, 2014; Moraes, Carrigan, \& Szmigin, 2012) focus proenvironmental behaviour on a one-dimensional approach when combating climate change challenges. These studies are either productor service-centric (for example, the adoption of environmental friendly products) or activity-centric (for example, recycling or green tourism). While environmental issues are multifaceted matters with spiralling effects, human behaviour is fluid and non-uniform. Therefore, proenvironmental behaviours can occur in an individual via different forms such as by purchasing energy efficient light bulbs for use, reusing packagings, switching from private to public transportations and others (Barr, Shaw, \& Coles, 2011).

Scholars (Akenji, 2014; Leonidou \& Leonidou, 2011; Sheth et al., 2011; Mont \& Plepys, 2008) state that lifestyle-centric pro-environmental behaviours promote a better understanding of the role of consumption. It addresses environmental challenges, and it encourages proenvironmental adoption of both green and non-green products or services. Lifestyle-centric pro-environmental behaviours is an easier route for individuals because it increases the individuals realisation in making contributions to the environment. Carrington et al. (2010) stated that the availability of opportunity and situation is one of the factors deterring individuals from enacting their pro-environmental behaviour intentions. Under familiar settings and routines, individuals will experience a shorter learning curve when adopting pro-environmental behaviours, thus individuals can transit into the pro-environmental behaviour effortlessly.

As the individuals' alignment towards renewed pro-environmental behaviour is beyond consumption or utilitarian orientation (Shaw et al., 2016), this study will thus define pro-environmental behaviours with respect to individuals who modify their consumption behaviour by adopting any of the three sustainable modes of reduce, recycle and 
reuse (Moraes et al., 2012). This study will not focus on the individuals' particular product or service orientation when dealing with the environmental phenomenon. In the context of this study, to reduce means to minimise household or domestic waste generated in daily activities (Sheth et al., 2011), reuse activities refer to the repeated use of things or materials either in part or whole, with its original function (Kirchherr, Reike, \& Hekkert, 2017; Roberts \& Bacon, 1997), for example clothings and furniture, and recycle activities refer to the repurposing of things which cannot be reused (Papaoikonomou et al., 2012; Rezai, Teng, Mohamed, \& Shamsudin, 2012), for instance glass bottles recycled into vases. These three modes of pro-environmental behaviour and their benefits are noted in various studies (Akenji, 2014; Leonidou \& Leonidou, 2011; Sheth et al., 2011; Mont \& Plepys, 2008; Steinhorst, Klöckner, \& Matthies, 2015).

\subsection{Attitude}

Attitude is a latent layer of reference point in an individual's cognitive process. It is the affection an individual holds towards a specific product, brand or behaviour (Bhattacharyya \& Cummings, 2014; Secchi, 2009). Attitude can also be the state of an emotion, whether negative or positive, acting as a precursor for the pro-environmental behaviour. At the helm of the individual's thought process, attitude drives behavioural change. Considering that attitude can predict behaviour, it is important to understand when and which kind of attitude can predict behavioural change so as to understand how individuals behave in relation to environmental issues (Miller \& Peterson, 2004; Clary et al., 1998).

Having a positive attitude towards pro-environmental activities such as ecotourism (Zhang \& Lei, 2012) is a precursor of the individual's behavioural intention (Carrington et al., 2010). This can generate an active involvement in pro-environmental behaviours (Cho, Thyroff, Rapert, Park, \& Lee, 2012). However, Cornelissen, Pandelaere, Warlop and Dewitte (2008) asserted that attitude towards ecological behaviours can be changed, moulded and influenced. This can be achieved by understanding the component elements and by exploring the positive cues that can increase the participation of environmental behaviours. In this regard, the following hypothesis is developed:

$\mathrm{H}_{1}$ : There is a positive relationship between attitude and proenvironmental behaviours. 


\subsection{Social Cognitive Theory - Perceived Self-efficacy}

Sustainable behaviour is motivated by intrinsic and extrinsic factors which include the individual's characteristics and the conversion incentives of the environment (Caruana, Carrington, \& Chatzidakis, 2015; Shaw et al., 2016; Breunig, Murtell, Russell, \& Howard, 2014; McDonagh \& Prothero, 2014; Moraes et al., 2012; Soyez, 2012; Videras, Owen, Conover, \& Wu, 2012). Intrinsic factors are the internal elements that drive the individuals to perform something while extrinsic factors are related to external motivations.

In a situation where there is disagreement between the individual's cognition and behaviour, the individual would experience uncomfortable feelings. This motivates the individual to re-resonate between his/ her beliefs and behaviour so as to attain equilibrium. This is because the individual has an inner drive to harmonise the cognition and the behaviour so as to reduce the discomfort, thereby restoring balance and consistency of cognition and behaviour (Juvan \& Dolnicar, 2014; Poortinga et al., 2013).

The social cognitive theory provides a clearer way of understanding how the individual's behaviour functions by giving focus to selfefficacy. According to Bandura (2001), self-efficacy is one of the important concepts in human functionality. It is the core determinant for an individual to regulate and reflect on his/her own behaviour (Bandura, 1991). It is not a genetically endowed personality trait, rather it highlights an individual's goal-oriented capability of coordinating his/ her skills and abilities so as to achieve the desired goal in a particular sphere. The individual's self-efficacy beliefs are established across spatial and temporal variations and experiences.

Self-efficacy is the self-evaluation of one's capability and controllability (Gist, 1987). An individual makes a decision based on his/ her own reflection of his/her capabilities and abilities. It is the belief which the individual has of him/herself in managing the ability to achieve a desired goal (Ajzen, 2002; Ryan \& Deci, 2017). According to Bandura (1991), self-efficacy is the individual's self-system. It helps the individual to monitor and gauge his/her personal standard; it also helps the individual to evaluate different aspects of his/her behaviour and reaction according to post-performance behaviours. Individuals with high self-efficacy believe that they have the capability to act towards the desired goal while individuals with low self-efficacy will not pursue the desired goal because they perceive the task to be beyond their capability. 
This phenomenon can occur even in the presence of opportunities within their surroundings (Jin, 2013b; Bandura, 1991).

The belief in self-efficacy is a manifestation of self-confidence within a given environmental setting. It leads an individual to invest his/ her efforts into a pattern of thoughts, whether optimistic or pessimistic (Bandura, 1991, 2001). Self-efficacy belief can influence the way people cope with efficacy. It also helps to shield people from mental pressure, subsequently strengthening their attitude towards an object. Individuals with a higher level of perceived self-efficacy are confident of their own effectiveness and competencies. Their actions are based on a clear understanding and awareness about the consequences and implications. Self-efficacy can also cushion attitude change due to negative feelings such as anxiety which arose from uncertainty or barriers encountered while performing certain pro-environmental activities. Undoubtedly, individuals with higher perceived self-efficacy will proactively be sourcing for satisfaction solutions to overcome such barriers. Therefore, perceived self-efficacy can be a resistance to any counter persuasion since it enables the individual to maintain his/her behaviour across times and settings (Bandura, 1991, 2001; Vallacher \& Wegner, 1989). In this regard, self-efficacy belief can consequently determine whether people would react positively or negatively in a particular situation.

The social cognitive theory predicts that people who see attitude as important and relevant to self-efficacy not only develop favourable attitudes towards sustainable behaviour, they also have higher levels of attitude stability (Moore \& Homer, 2008; Glasman \& Albarracin, 2006). The theory states that perceived self-efficacy has an effect in fostering the attitude which maintains the consistency of attitude-sustainable behaviour relationship. The theory also maintains that perceived self-efficacy serves as a dual mechanism on attitude and behaviour. Premised on the confidence in capabilities, it helps the individual to execute a goal. Perceived self-efficacy can function as a navigation tool which orchestrates the individual's resources towards a goal. It also enables the individual to counteract other external factors that challenge the individual's attitude. Based on the above discussions, this study hypothesised that perceived self-efficacy is able to mitigate the effect of environmental deficiencies which impede the individual from pursuing his/her pro-environmental goal persistently. Thus, the current study aims to examine the effect of perceived self-efficacy on both attitude and pro-environmental behaviours. The hypotheses thus formulated are as follows: 
$\mathrm{H}_{2}$ : There is a positive relationship between perceived self-efficacy and attitude.

$\mathrm{H}_{3}$ : There is a positive relationship between perceived self-efficacy and pro-environmental behaviours.

The three hypothetical relationships formulated for this study are depicted in Figure 1.

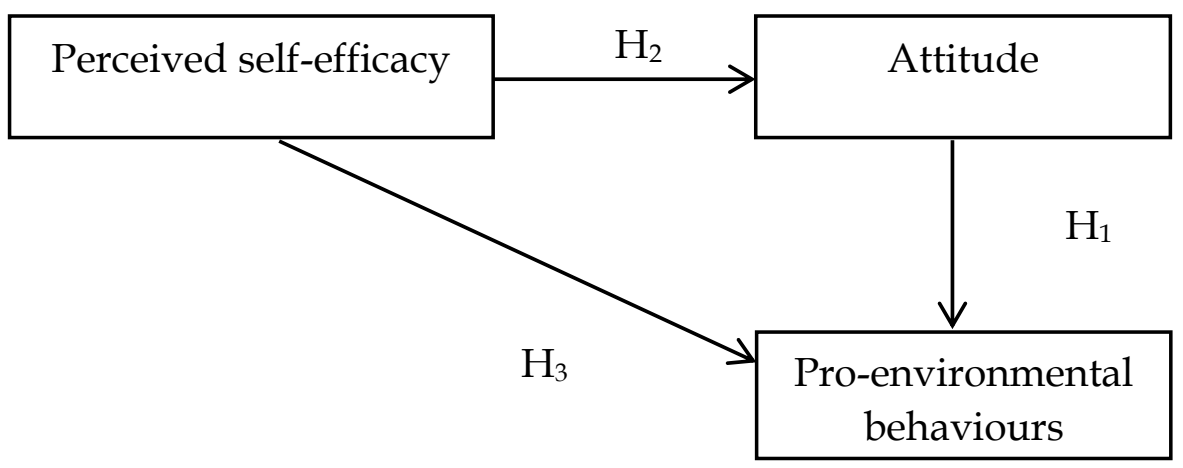

Figure 1: Research Framework

\section{Methodology}

\subsection{Measure of Constructs}

The constructs used in this study were adapted from literature to suit the context of this study (Appendix 1). In this regard, human behaviour is considered to be a fluid-like substance and is non-uniform and proenvironmental behaviours is deemed to occur within an individual through different modes such as reduce, re-use and recycle (Barr et al., 2011). Pro-environmental behaviours is operationalised as a wide spectrum of daily activities. For the purpose of this study, twelve items were adapted from scholars (Memery, Megicks, Angell, \& Williams, 2012; Rezai et al., 2012; Han, Hsu, \& Lee, 2009; Welsch \& Kühling, 2009) to measure the pro-environmental behaviours, thirteen items were adapted from Jin (2013a, 2013b) and Schwarzer and Jerusalem (1995) to measure perceived self-efficacy and eight items were adapted from Boschetti, Richert, Walker, Price, and Dutra (2012) to measure attitude. 


\subsection{Survey Administration and Sample}

This study employs the survey method. A questionnaire was developed based on the constructs adapted from literature so as to test the conceptual model and the hypotheses. The questionnaire was then piloted on 20 individual respondents. The feedback (e.g., inconsistency of wording, unclear or ambiguous items) from the pilot study was then used to refine the questions for a larger study.

Stratified random sampling technique was applied based on geographical location so as to avoid cases where members of the population would be significantly over or under represented (Churchill, 1996). This is an important consideration because in Malaysia, the local authorities are responsible for waste management. Consequently, the variations and effects across different geographical areas were considered. The samples were divided into five geographical regions of Malaysia: Northern, Central, Southern, the East Coast of Malaysia and East Malaysia. Thirteen towns were selected from these five geographical regions as shown in Table 1.

The distribution of the questionnaire was conducted based on the mall-intercept technique. For each of the towns selected, we identified a list of shopping malls. A call was made to the respective management of these shopping malls to obtain the number of mall visitors who visited

Table 1: Town and Shopping Malls Selected

\begin{tabular}{lll}
\hline Regions & Towns & Shopping Malls \\
\hline Central & Petaling Jaya & One Utama \\
& Damansara Utama & Tropicana City Mall \\
& Subang Jaya & Subang Parade \\
Northern & Seberang Jaya & Sunway Carnival Mall \\
& George Town & Gurney Plaza \\
& Air Hitam & Sunshine Farlim Mall \\
Southern & Plentong & Giant Plentong Mall \\
& Nusa Damai & ECO \\
& Johor Bharu & AEON Tebrau \\
East Coast & Bentong & Bentong Vega Mall \\
East Malaysia & Kuantan & Kuantan City Mall \\
& Kota Kinabalu & Imago \\
\hline
\end{tabular}


each day. Based on the share of the shopping malls, we further selected one specific shopping mall. Permission to distribute the questionnaires was granted by the respective mall management prior to commencing the survey.

This study employed quota sampling as an approach where we selected 200 shoppers as our participants for each of the shopping mall. Prospective respondents were politely recruited as they exited from the mall. These participants, however, had to fulfil the selection criteria which encompass ethnicity, gender, age distribution, day of week and time of day so as to avoid systematic biases. A total of 2,600 questionnaires were distributed and the survey was conducted from 28 March 2015 to 2 September 2015 including weekdays and weekends. This helped to ensure that a wider range of profiles could be captured. Of the 2,600 questionnaires distributed, only 500 responses were obtained, generating 19 per cent response rate.

Table 2 depicts the respondents' profile. Sixty seven per cent of the respondents were Malays and Bumiputera, 25 per cent were Chinese, and eight per cent were Indians and others. Gender-wise, 52 per cent of the respondents were males and 48 per cent were females. This study include respondents aged 18 years old and above with 43 per cent being in the 18-35 age while 57 per cent were above 35 years old. About 68 per cent of the respondents were married with one out of two (50 per cent) married respondents having 1-2 children. The survey noted that

Table 2: Respondents' Profiles

Frequency Percentage

Region

Central

225

45

Northern

Southern

East Coast

East Malaysia

Gender

Male

Female

Ethnicity

Malays and Bumiputera $\quad 335$

Chinese 
Table 2: (continued)

Frequency Percentage

Age

18 - 25 years old

75

15

26 - 35 years old

$36-45$ years old

140

20

46 - 55 years old

17

56 years old and above

Marital status

Married

68

Single

339

32

Number of children

None

10

1-2

50

50

3-4

250

34

$>5$

30

6

Household size

1-2 persons

46

3-4 persons

196

9

5-6 persons

186

39

7 persons or more

37

$72 \quad 14$

Highest level of education attained

Primary or less

Secondary

$\begin{array}{ll}4 & 1\end{array}$

Form 6/Pre-University or equivalent

College/Diploma/Vocational education or equivalent

Degree

Master degree and above

Professional courses/program

\section{Employment}

Middle management or higher

Professional staff/supervisor/leader/engineer

Support staff/non-executive staff/administrative

Self-employed

Unemployed, students, retirees and housewives

98

20

\section{Monthly personal gross income}

Less than RM2,000

RM2,000 - RM3,999

RM4,000 - RM5,999

96

19

RM6,000 - RM7,999

RM8,000 and above 
39 per cent of the households comprised three to four members while 37 per cent stated that there were 5-6 persons in their households. From the socio-economic status, majority (76 per cent) of the respondents had attained at least a diploma or higher-level qualifications and 64 per cent of them were employed. Around 37 per cent reported having a monthly personal gross income of RM4,000 and above while 62 per cent claimed that their incomes were below RM4,000. Majority of the respondents were also above the Malaysian individuals' median monthly salaries and wages, specifically RM1,700 per month. This figure is in line with the statistics published by Khazanah Research Institute (2014).

\section{Analysis and Findings}

\subsection{Pro-environmental Behaviours' Profile}

The respondents' pro-environmental related activities are shown in Table 3. The figure indicates that reducing consumption activities occur more when compared to the recycling or reusing activities. These results imply that the respondents were concious when it comes to utility consumption, specifically electricity and water consumption (Welsch \& Kühling, 2009).

\subsection{Measurement Model}

A measurement model comprising all the three constructs, specifically pro-environmental behaviour, perceived self-efficacy and attitude were evaluated for validity and reliability. Traditionally, Cronbach's alpha is used to assess the internal consistency in social science research. However, applying Cronbach's alpha in PLS-SEM tends to generate conservative measurements and several researchers (Bagozzi \& Yi, 1988; Hair, Sarstedt, Ringle, \& Mena, 2012) have suggested using composite reliability as a replacement. In the context of this study, the internal consistency of the model was thus evaluated based on the composite reliability values. As depicted in Table 4, all the constructs have composite reliability of above 0.708 , indicating that all the items are measuring the same phenomenon and they correlated highly with the respective constructs (Hair, Hult, Ringle \& Sarstedt, 2014).

The measurement model was then assessed for convergent validity. Two dimensions were examined, namely (a) the outer loadings for each construct, where the outer loading value for all indicators should 
Table 3: Activities Involve/Participate (percentage)

\begin{tabular}{|c|c|c|c|c|}
\hline & Activities & Often & Occasionally & Never \\
\hline \multirow[t]{4}{*}{ Reduce } & $\begin{array}{l}\text { Reduce electricity consumption by } \\
\text { turning off lights and using } \\
\text { more energy efficiency appliances }\end{array}$ & 89 & 11 & 0 \\
\hline & $\begin{array}{l}\text { Make an effort to reduce water } \\
\text { consumption }\end{array}$ & 89 & 10 & $0^{*}$ \\
\hline & $\begin{array}{l}\text { To buy fruits, vegetables and other } \\
\text { groceries that are labelled as organic } \\
\text { products }\end{array}$ & 50 & 49 & 2 \\
\hline & $\begin{array}{l}\text { Consciously choose to reduce } \\
\text { consumption }\end{array}$ & 75 & 24 & $0^{*}$ \\
\hline \multirow[t]{5}{*}{ Recycle } & $\begin{array}{l}\text { Recycle plastics, glass, papers and } \\
\text { other packaging materials }\end{array}$ & 76 & 22 & 1 \\
\hline & Make use of recycling facilities & 67 & 32 & 2 \\
\hline & $\begin{array}{l}\text { Use recyclable shopping bags when } \\
\text { going for shopping }\end{array}$ & 64 & 33 & 3 \\
\hline & Store materials for recycling & 74 & 25 & 1 \\
\hline & $\begin{array}{l}\text { Separate and dispose all recyclable } \\
\text { materials }\end{array}$ & 68 & 30 & 2 \\
\hline \multirow[t]{3}{*}{ Reuse } & $\begin{array}{l}\text { Reuse or amend items rather than } \\
\text { throw them away }\end{array}$ & 67 & 32 & 2 \\
\hline & $\begin{array}{l}\text { Buy products in packages that can } \\
\text { be refilled }\end{array}$ & 73 & 26 & 1 \\
\hline & Look for ways to reuse things & 69 & 29 & 1 \\
\hline
\end{tabular}

Note: * Indicates less than $1 \%$.

be above 0.7 or higher for further investigation, and (b) the average extracted variance (AVE) where all constructs should reach above the critical value of 0.5 (Chen \& Peng, 2012; Parzefall \& Kuppelwieser, 2012; Hair, Black, Babib \& Anderson, 2009; Reisinger \& Mavondo, 2007). In this study, both the outer loadings and the AVE were examined simultaneously. This step was performed so as to determine whether the removal of any item needs to be done so as to increase the AVE value. Any item with an outer loading of below 0.4 was eliminated (Hair et al., 2014). There were two items with outer loadings below 0.4 specifically, ATT3 and ATT4. Removal decision for these indicators was made using 


\begin{tabular}{|c|c|c|c|c|}
\hline & & $\begin{array}{l}\text { Outer } \\
\text { Loading }\end{array}$ & $\begin{array}{l}\text { Composite } \\
\text { Reliability }\end{array}$ & AVE \\
\hline \multicolumn{2}{|c|}{ Attitude (ATT) } & & 0.876 & 0.614 \\
\hline ATT1 & $\begin{array}{l}\text { I am personally committed toward } \\
\text { preventing environmental problems. }\end{array}$ & 0.801 & & \\
\hline ATT2 & $\begin{array}{l}\text { I am personally committed toward } \\
\text { improving environmental problems. }\end{array}$ & 0.807 & & \\
\hline ATT3 & $\begin{array}{l}\text { Environmental problems are as important } \\
\text { as many other problems facing by the } \\
\text { world today. }\end{array}$ & Deleted & & \\
\hline ATT4 & $\begin{array}{l}\text { I am concerned about environmental } \\
\text { problems because of the potential } \\
\text { consequences on my wealth. }\end{array}$ & Deleted & & \\
\hline ATT5 & $\begin{array}{l}\text { I am concerned about environmental } \\
\text { problems because of the potential } \\
\text { consequences on my lifestyle. }\end{array}$ & 0.719 & & \\
\hline ATT6 & $\begin{array}{l}\text { I am concerned about environmental } \\
\text { problems because of the potential } \\
\text { consequences on my health. }\end{array}$ & 0.757 & & \\
\hline ATT7 & $\begin{array}{l}\text { I am concerned about environmental } \\
\text { problems because of the potential } \\
\text { consequences on my community. }\end{array}$ & 0.832 & & \\
\hline ATT8 & $\begin{array}{l}\text { I am concerned about environmental } \\
\text { problems because of the potential } \\
\text { consequences on the world. }\end{array}$ & 0.780 & & \\
\hline \multicolumn{2}{|c|}{ Perceived self-efficacy (PSE) } & & 0.942 & 0.590 \\
\hline PSE1 & $\begin{array}{l}\text { I can practice pro-environmental activities } \\
\text { very easily. }\end{array}$ & 0.717 & & \\
\hline PSE2 & $\begin{array}{l}\text { I think that my ability to adopt pro- } \\
\text { environmental lifestyle is greater } \\
\text { than others. }\end{array}$ & 0.735 & & \\
\hline PSE3 & $\begin{array}{l}\text { I am able to understand the ways of } \\
\text { sustaining the environment and apply it } \\
\text { effectively. }\end{array}$ & 0.770 & & \\
\hline PSE4 & $\begin{array}{l}\text { I can solve difficult problems if I try hard } \\
\text { enough. }\end{array}$ & 0.723 & & \\
\hline PSE5 & $\begin{array}{l}\text { If someone opposes me, I can find the } \\
\text { means and ways to get what I want. }\end{array}$ & 0.630 & & \\
\hline PSE6 & $\begin{array}{l}\text { It is easy for me to stick to my aims and } \\
\text { accomplish my goals. }\end{array}$ & 0.785 & & \\
\hline PSE7 & $\begin{array}{l}\text { I am confident that I could deal efficiently } \\
\text { with unexpected events. }\end{array}$ & 0.829 & & \\
\hline
\end{tabular}


Table 4: (continued)

\begin{tabular}{|c|c|c|c|c|}
\hline & & $\begin{array}{l}\text { Outer } \\
\text { Loading }\end{array}$ & $\begin{array}{l}\text { Composite } \\
\text { Reliability }\end{array}$ & AVE \\
\hline PSE8 & $\begin{array}{l}\text { Thanks to my resourcefulness, I know how } \\
\text { to handle unforeseen situations. }\end{array}$ & 0.810 & & \\
\hline PSE9 & $\begin{array}{l}\text { I can solve most problems if I invest the } \\
\text { necessary effort. }\end{array}$ & 0.806 & & \\
\hline PSE10 & $\begin{array}{l}\text { I can remain calm when facing difficulties } \\
\text { because I can rely on my coping abilities. }\end{array}$ & 0.758 & & \\
\hline PSE11 & $\begin{array}{l}\text { When I am confronted with a problem, } \\
\text { I can usually find several solutions. }\end{array}$ & 0.815 & & \\
\hline PSE12 & $\begin{array}{l}\text { If I am in trouble, I can usually think of a } \\
\text { solution. }\end{array}$ & 0.828 & & \\
\hline PSE13: & $\begin{array}{l}\text { I can usually handle whatever comes } \\
\text { my way. }\end{array}$ & 0.757 & & \\
\hline Reduce & & & 0.771 & 0.597 \\
\hline ReD1 & $\begin{array}{l}\text { Reduce electricity consumption by } \\
\text { turning off lights and using more energy } \\
\text { efficiency appliances. }\end{array}$ & 0.754 & & \\
\hline ReD2 & $\begin{array}{l}\text { Make an effort to reduce water } \\
\text { consumption. }\end{array}$ & 0.850 & & \\
\hline ReD3 & $\begin{array}{l}\text { Try to buy fruits, vegetables and other } \\
\text { groceries that are labelled as organic } \\
\text { products. }\end{array}$ & 0.655 & & \\
\hline ReD4 & Consciously choose to reduce consumption. & 0.817 & & \\
\hline \multicolumn{2}{|l|}{ Recycle } & & 0.900 & 0.715 \\
\hline $\mathrm{ReC1}$ & $\begin{array}{l}\text { Recycle plastics, glass, papers and other } \\
\text { packaging materials. }\end{array}$ & 0.856 & & \\
\hline $\mathrm{ReC} 2$ & Make use of recycling facilities. & 0.840 & & \\
\hline $\mathrm{ReC} 3$ & $\begin{array}{l}\text { Use recyclable shopping bag when going } \\
\text { for shopping. }\end{array}$ & 0.785 & & \\
\hline $\mathrm{ReC} 4$ & Store materials for recycling. & 0.875 & & \\
\hline $\mathrm{ReC5}$ & $\begin{array}{l}\text { Separate and dispose all recyclable } \\
\text { materials. }\end{array}$ & 0.868 & & \\
\hline Reuse & & & 0.896 & 0.827 \\
\hline ReU1 & $\begin{array}{l}\text { Reuse or amend items rather than throw } \\
\text { them away. }\end{array}$ & 0.909 & & \\
\hline ReU2 & $\begin{array}{l}\text { Buy products in packages that can be } \\
\text { refilled. }\end{array}$ & 0.902 & & \\
\hline ReU3 & Look for ways to reuse things. & 0.917 & & \\
\hline
\end{tabular}

Note: ATT 3 and ATT4 were excluded from further analysis, as they have loadings below 0.4 . 
the AVE as a guideline. When the first item (ATT3) was removed from Attitude (ATT), the ATT's AVE value increased from 0.477 to 0.545; and upon removal of the second item (ATT4), the result of the AVE for ATT rose even further to 0.614 . Consequently, these two items were removed from ATT.

In this study, discriminant validity was also performed to ensure that no constructs overlapped, and that each individual construct is unique and distinct from other constructs. Three methods of the PLS-SEM were used to validate the discriminant validity (Hair et al., 2014) namely: (a) cross leading, (b) Fornell-Larcker criterion, and (c) Heterotrait-Monotrait Ratio (HTMT). Cross loading assessment was done to assess whether each item's outer loading on an associated construct is greater than the loadings on the other constructs. Table 5 shows all the items for each construct that meets the cross loading criteria, where all the items loaded highly on their respective construct, as compared to other constructs. All the constructs were also found to satisfy the Fornel-Larcker criterion (Hair et al., 2014), where the diagonal value, which is the squared root of the AVE of a specific construct, was found to be greater than the cross-correlation with other constructs (Table 6).

Discriminant validity was further analysed using the HeterotraitMonotrait Ratio (HTMT), which compares the correlation of items across constructs to measure different phenomena and the correlation of items within the same construct for the same phenomena (Hair et al., 2014; Henseler, Ringle, \& Sarstedt, 2014). The boot-strapping on HTMT inference yielded HTMT values that were significantly lower than 1 (Table 7).

Taken as a whole, all the constructs in the study were found to satisfy the validity and reliability assessments. In this study, the proenvironmental behaviours (PEB) being discussed were composed of three modes: reduce, reuse and recycle. Hence, the remaining analysis of this study will be based on the second order construct so as to assess the significant effect between the independent and the dependent variables in a parsimonious model. The second order construct for PEB was found to be valid and reliable where its composite reliability value is above 0.708 (Hair et al., 2014), and the average variance extracted (AVE) is greater than 0.5 (Chen \& Peng, 2012; Parzefall \& Kuppelwieser, 2012; Hair et al., 2009; Reisinger \& Mavondo, 2007) (Table 8). Therefore, the second order construct for PEB is now ready for the next stage of assessment (Table 9). 
Table 5: Discriminant Validity - Cross Loading

\begin{tabular}{lccccc}
\hline & ATT & PSE & Reduce & Recycle & Reuse \\
\hline ATT1 & 0.801 & 0.568 & 0.456 & 0.418 & 0.465 \\
ATT2 & 0.807 & 0.585 & 0.478 & 0.452 & 0.464 \\
ATT5 & 0.719 & 0.430 & 0.255 & 0.238 & 0.261 \\
ATT6 & 0.757 & 0.375 & 0.224 & 0.225 & 0.255 \\
ATT7 & 0.832 & 0.520 & 0.345 & 0.367 & 0.404 \\
ATT8 & 0.780 & 0.490 & 0.293 & 0.315 & 0.369 \\
PSE1 & 0.618 & 0.717 & 0.427 & 0.443 & 0.451 \\
PSE2 & 0.511 & 0.735 & 0.343 & 0.356 & 0.371 \\
PSE3 & 0.636 & 0.770 & 0.395 & 0.409 & 0.443 \\
PSE4 & 0.567 & 0.723 & 0.228 & 0.242 & 0.331 \\
PSE5 & 0.379 & 0.630 & 0.246 & 0.146 & 0.245 \\
PSE6 & 0.426 & 0.785 & 0.306 & 0.276 & 0.325 \\
PSE7 & 0.430 & 0.829 & 0.272 & 0.300 & 0.344 \\
PSE8 & 0.393 & 0.810 & 0.272 & 0.287 & 0.316 \\
PSE9 & 0.476 & 0.806 & 0.230 & 0.241 & 0.303 \\
PSE10 & 0.426 & 0.758 & 0.257 & 0.262 & 0.307 \\
PSE11 & 0.526 & 0.815 & 0.342 & 0.256 & 0.322 \\
PSE12 & 0.496 & 0.828 & 0.308 & 0.252 & 0.304 \\
PSE13 & 0.343 & 0.757 & 0.223 & 0.211 & 0.273 \\
ReD1 & 0.326 & 0.307 & 0.754 & 0.470 & 0.417 \\
ReD2 & 0.372 & 0.298 & 0.850 & 0.531 & 0.474 \\
ReD3 & 0.310 & 0.291 & 0.655 & 0.436 & 0.452 \\
ReD4 & 0.394 & 0.336 & 0.817 & 0.561 & 0.497 \\
ReC1 & 0.376 & 0.273 & 0.591 & 0.856 & 0.593 \\
ReC2 & 0.372 & 0.361 & 0.605 & 0.840 & 0.638 \\
ReC3 & 0.361 & 0.311 & 0.494 & 0.785 & 0.580 \\
ReC4 & 0.387 & 0.328 & 0.508 & 0.875 & 0.666 \\
ReC5 & 0.388 & 0.355 & 0.546 & 0.868 & 0.696 \\
ReU1 & 0.432 & 0.350 & 0.520 & 0.750 & 0.909 \\
ReU2 & 0.429 & 0.415 & 0.535 & 0.630 & 0.902 \\
ReU3 & 0.471 & 0.459 & 0.571 & 0.668 & 0.917 \\
\hline & & & & &
\end{tabular}


Table 6: Discriminant Validity - Fornell-Lacker Criterion

\begin{tabular}{llllll}
\hline & ATT & PSE & Recycle & Reduce & Reuse \\
\hline ATT & 0.783 & & & & \\
PSE & 0.645 & 0.768 & & & \\
Recycle & 0.446 & 0.385 & 0.845 & & \\
Reduce & 0.456 & 0.399 & 0.650 & 0.773 & \\
Reuse & 0.488 & 0.448 & 0.752 & 0.596 & 0.910 \\
\hline
\end{tabular}

Table 7: Discriminant Validity - Heterotrait-Monotrait ratio (HTMT)

\begin{tabular}{lccccc}
\hline & ATT & PSE & Recycle & Reduce & Reuse \\
\hline ATT & & & & & \\
PSE & 0.671 & & & & \\
Recycle & 0.482 & 0.401 & & & \\
Reduce & 0.529 & 0.454 & 0.779 & 0.720 & \\
Reuse & 0.531 & 0.474 & 0.835 & & \\
\hline
\end{tabular}

Table 8: Result Summary for Validity and Reliability Tests for Pro-Environmental Construct

\begin{tabular}{lccc}
\hline & Composite Reliability & AVE & Discriminant Analysis \\
\hline Reduce & 0.771 & 0.597 & YES \\
Recycle & 0.900 & 0.715 & YES \\
Reuse & 0.896 & 0.827 & YES \\
\hline
\end{tabular}

Note: Indicator reliability = Outer loading with the power of 2 .

Table 9: Weights of First-Order Constructs on the Designated Second-Order Construct

\begin{tabular}{llrrr}
\hline $\begin{array}{l}\text { Second Order } \\
\text { construct }\end{array}$ & $\begin{array}{l}\text { First Order } \\
\text { construct }\end{array}$ & Weights & t-values & p-values \\
\hline Pro-environmental & Recycle & 0.936 & 146.458 & $0.000^{*}$ \\
behaviours (PEB) & Reduce & 0.820 & 45.688 & $0.000^{*}$ \\
& Reuse & 0.882 & 65.408 & $0.000^{*}$ \\
\hline
\end{tabular}

Note: *Significant value at 0.001 . 
All the constructs hypothesised in the present study were examined. There was no evidence to indicate collinearity between the constructs (Table 10). This outcome is further supported by the VIF values for all the constructs which is less than 5 (Hair et al., 2014).

Table 10: Collinearity Assessment: Inner Variance Inflation Factor (VIF) Values

\begin{tabular}{lcc}
\hline & ATT & PEB \\
\hline ATT & & 1.880 \\
PSE & 1.467 & 2.157 \\
\hline
\end{tabular}

\subsection{Structural Model Analysis}

The structural model relationships were examined for their significance and also to test the hypotheses. Through bootstrapping with an iteration of 2,500, the examination of the hypotheses was based on a significance level of five per cent, $(5 \%)$, on the one-tail test with a $t$-value of above 1.645. As shown in Table 11, the relationship between attitude (ATT) and pro-environmental behaviours (PEB) was found to be positive $(\beta=0.290$; $\mathrm{t}=5.702 ; \mathrm{p}<0.05$ ) while perceived self-efficacy (PSE) was found to have a positive relationship with attitude $(\mathrm{ATT})(\beta=0.478 ; \mathrm{t}=10.607 ; \mathrm{p}<0.05)$.

Table 11: Path Coefficients

\begin{tabular}{llcccc}
\hline $\begin{array}{l}\text { Hypo- } \\
\text { theses }\end{array}$ & Path & $\begin{array}{c}\text { Path } \\
\text { Coefficients }\end{array}$ & $\begin{array}{c}\mathrm{t}- \\
\text { values }\end{array}$ & $\begin{array}{c}\mathrm{p}- \\
\text { values }\end{array}$ & Results \\
\hline 1 & $\begin{array}{l}\text { Attitude (ATT) } \rightarrow \\
\text { pro-environmental } \\
\text { behaviours (PEB) }\end{array}$ & 0.290 & 5.702 & $0.000^{*}$ & accepted \\
2 & $\begin{array}{l}\text { Perceived self- } \\
\text { efficacy (PSE) } \\
\text { attitude (ATT) }\end{array}$ & 0.478 & 10.607 & $0.000^{*}$ & accepted \\
3 & $\begin{array}{l}\text { Perceived self- } \\
\text { efficacy (PSE) } \rightarrow \\
\text { pro-environmental } \\
\text { behaviours (PEB) }\end{array}$ & 0.060 & 1.098 & 0.136 & rejected \\
\hline
\end{tabular}

Note: *Significance level, $\mathrm{p}<0.05$, $\mathrm{t}$-value at one-tail $=1.645$. 
Therefore, $\mathrm{H}_{1}$ and $\mathrm{H}_{2}$ were supported. In contrast, the relationship between perceived self-efficacy and pro-environmental behaviours was found to be not significant $(\beta=0.060 ; \mathrm{t}=1.098 ; \mathrm{p}>0.05)$. Therefore, $\mathrm{H}_{3}$ was rejected. Table 11 shows the results of the hypothetical relationships.

As $\mathrm{H}_{3}$ was rejected, this study performed an additional subgroup analysis to futher determine whether the result will remain similar with respondents who have higher pro-environmental behaviours. The derived mean score for pro-environmental behaviours was dichotomised into two different levels which include a high level with a score above the mean score and a low level where the score is below the derived mean score for pro-enviroment behaviours. Group 1 featured respondents with high engagement in pro-environmental behaviours and Group 2 featured respondents with low engagement in proenvironmental behaviours.

The result drawn from Group 1 showed a positive relationship between perceived self-efficacy and pro-environmental behaviour. In contrast, there was no significant relationship between perceived selfefficacy and pro-environmental behaviour among Group 2 respondents with low levels of pro-environmental behaviour $(\beta=-0.011 ; t=0.123$, $\mathrm{p}>0.05$ ) (Tables 12 and 13).

Table 12: Path Coefficients among High Level of Pro-Environmental Behaviours

\begin{tabular}{lccr}
\hline & Path Coefficients & t-values & p-values \\
\hline $\begin{array}{l}\text { Perceived self-efficacy (PSE) } \rightarrow \\
\text { pro-environmental behaviours } \\
(\text { PEB })\end{array}$ & 0.138 & 1.871 & $0.031^{*}$ \\
\hline
\end{tabular}

Note: * Significance level, $\mathrm{p}<0.05$, $\mathrm{t}$-value at one-tail $=1.645$.

Table 13: Path Coefficients among Low Level of Pro-Environmental Behaviours

\begin{tabular}{lccr}
\hline & Path Coefficients & t-values & p-values \\
\hline $\begin{array}{l}\text { Perceived self-efficacy (PSE) } \rightarrow \\
\text { pro-environmental behaviours } \\
(\text { PEB })\end{array}$ & -0.011 & 0.123 & 0.451 \\
\hline
\end{tabular}

Note: Significance level, $\mathrm{p}<0.05, \mathrm{t}$-value at one-tail $=1.645$. 


\section{Discussion}

This study has examined the effect of perceived self-efficacy on attitude and pro-environment behaviours of 500 respondents. In line with $\mathrm{H}_{1}$, attitude has a positive relationship with pro-environmental behaviours in daily activities. Perceived self-efficacy also has a positive effect on attitude. However, the positive relationship between perceived selfefficacy and pro-environmental behaviours was only reported by individuals with high levels of pro-environmental behaviours.

\subsection{Attitude and Pro-environmental Behaviours}

Attitude can act as a reference frame for individuals to persist in reaching their desired behaviours (Akenji, 2014) since attitude has a significant relationship with pro-environmental behaviours, as supported by existing findings (White \& Simpson, 2013; Cho et al., 2013; Zhang \& Lei, 2012; Carrington et al., 2010; Ramayah et al., 2010; Welsch \& Kühling, 2009; Cornelissen et al., 2008; Follows \& Jobber, 2000).

The individual's attitude towards pro-environmental behaviour is a high determinant of the individual's desire to improve his/her living conditions and in adapting to environmental issues. This is crucial for a country because environmental consequences create serious impacts on a community. Besides being influential as a predisposition that can cause potential consequences on the world, the individual's attitude towards a certain behaviour such as health and lifestyles can also create consequences leading to environmental problems. This observation is also supported by previous findings (Akenji, 2014; Bucic et al., 2012; Sheth et al., 2011) which showed that individual goals and standards are the key motivating factors for individuals to adopt sustainable behaviours such as showing higher relevancy and closeness to environmental issues, showing greater favourable attitude towards proenvironmental behaviours, and having lesser psychological distance with the environment (Cornelissen et al., 2008).

\subsection{Perceived Self-efficacy and Attitude}

The social cognitive theory states that perceived self-efficacy has a significant impact on attitude. Likewise, the result of this study shows that perceived self-efficacy has a significant positive effect on attitude, thereby supporting the theory and is consistent with existing literature 
(Jiang, 2015; Jin, 2013b; Moore \& Homer, 2008). It appears that perceived self-efficacy can steer an individual's attitude towards self-confidence in efficiently dealing with unexpected events; it also encourages selfinitiated solutions besides assisting the individuals in formulating alternate solutions for handling unforeseen situations.

Individuals have acknowledged that perceived self-efficacy enable their actions to be goal-oriented; it also helps them to understand and apply effective ways of sustaining the environment, including coping, handling and adopting capabilities that correspond to the environmental activities and lifestyles (Wilcox et al., 2009). Perceived self-efficacy can make individuals believe in their own efforts; it further enhances the individuals' confidence to practise pro-environmental activities with ease and so become capable of finding the resources, means and ways to react to any counteractions. This can subsequently lead to the development of a positive and confident attitude (Zunick, Teeny, \& Fazio, 2017).

The positive influence of perceived self-efficacy on attitude further suggests that perceived self-efficacy serves as a psychological mechanism which maintains and increases the individual's evaluation of his/her internal quality. Perceived self-efficacy plays a significant role in reinforcing attitude formation. This is supported by the social cognitive theory which states that an individual's belief in his/her ability to perform will have some effect on the selection process which regulates one's behaviours, one's coping capabilities, one's level of motivation, and one's goal accomplishment. It not only affects human functioning directly, but also indirectly, through its impact on other important determinants such as the selection process, motivation, affection or attitude (Bandura, 1993, 2001). Therefore, perceived self-efficacy occupies a focal and pervasive pivotal role in causal structures.

\subsection{Perceived Self-efficacy and Pro-environmental Behaviour}

The outcome drawn from this study does not support the hypothesised direct influence of perceived self-efficacy on pro-environmental behaviours. Nonetheless, further analysis of the effect of perceived selfefficacy on different levels of pro-environmental behaviour revealed that the relationship between perceived self-efficacy and pro-environmental behaviours is significant, particularly among those whose proenvironmental behaviour engagement is high. Results indicate that the 
higher the perceived self-efficacy is, the higher one's self-confidence in contributing to the environment through one's behaviour. This drives a higher level of pro-environmental engagement. The findings of this study suggest that high pro-environmental behaviour adoption is attributed to individuals who are confident that they can manoeuvre the challenges associated with pro-environmental behaviours.

In summary, this study has expanded knowledge on the stability of attitude and behaviour. This study also suggests that perceived selfefficacy has a direct influence on attitude. The positive relationship between perceived self-efficacy and attitude implies that perceived selfefficacy can strengthen one's attitude towards sustainable behaviour. With the presence of perceived self-efficacy, individuals will be more determined and more conscious of the consequences and effects of their own actions. They are also able to ascribe to the rationale of 'why' they acted in a certain way. As such, individuals will be consistent in their behaviour over time. Such individuals will choose an action that is aligned to their own capacity as supported by their own experiences (Steinhorst et al., 2015; Vallacher \& Wegner, 1989).

Perceived self-efficacy is a cognitive evaluation process. It functions in self-evaluation and is subsequently transmitted to attitude formation (Jiang, 2015). The efficacy belief posits significant motivating effects, where the belief influences an individual to adapt or make necessary changes corresponding to the situation; either through own behaviour or by influencing surrounding characteristics. The current results contribute to current literature not only by expanding the understanding of the contributing factor in building the strength of attitude and behaviour but also by providing evidence which depicts that perceived self-efficacy can be a resistance to counter persuasions (Cheatham \& Tormala, 2015).

\subsection{Implications}

The empirical evidence of this study points towards the congeniality of lifestyle-centric pro-environmental behaviours in daily routines within the personal setting. Driven by their attitude towards pro-environmental behaviours, individuals will strive to balance their environmental concerns with their capabilities and capacities (perceived self-efficacy).

Majority of the respondents in this study reported that they frequently and consciously reduce utility and other consumptions when compared to recycle and reuse activities. This may be explained by the fact that behaviour occurs in a personal setting and when 
coupled with a high level of perceived self-efficacy, the behaviour will contribute to lower adoption barriers. It is easier for the individuals to adopt consumption reduction as there is no need to seek external assistance unlike the other two activities of reuse and recycle which are subjected to external factors. For example, recycling facilities and the nature of reusing packagings rely on the support provided by external organisations. Therefore, policy makers need to strategise so as to target different levels of pro-environmental behaviour adopters. Doing so can facilitate self-help among the general public thereby, sustaining their pro-environmental behaviours.

Acknowledging that the adoption level of pro-environmental behaviour is different between individuals, this study has highlighted that perceived self-efficacy exerts different modus orientations to diffuse the behaviour. Since perceived self-efficacy can lead to high proenvironmental behaviour engagement, it is essential for marketers and the government to provide an environment that is conducive and does not limit behaviours.

The findings of this study can be used as a guideline by marketers to develop their persuasion tools which can engage and educate environmental information seekers and subsequently, institutionalise pro-environmental attitudes into the daily activities of the society (Breunig, Murtell, Russell, \& Howard, 2014; Hullett \& Boster, 2001). Even though this study could not yield sufficient evidence to support that perceived self-efficacy has a direct influence on pro-environmental behaviours adoption, there is a probability that perceived self-efficacy exerts divergent effect on different levels of pro-environmental behaviours. There was an evident positive relationship between perceived self-efficacy and behaviour among high level adopters. This implies that when individuals engage in pro-environment behaviour in their daily activities, the experiences are similar to the actual competencies required in their daily behaviour.

Since self-efficacy has emerged as a factor that can promote attitude and encourage a behaviour that can resist persuasion attempts, it is possible for a marketer to increase its intervention efforts by targeting specific control beliefs which can enhance controllability. Marketers could emphasise that it is possible that 'you' expose yourself and family members to disadvantages when 'you' disengage from proenvironmental behaviours. Campaigns should emphasise that proenvironmental behaviours can happen in daily activities without requiring extra efforts such as reduce, reuse and recycle. 
The findings of this paper expand on literature by providing an understanding of the motivational factors underpinning proenvironmental behaviours which is beyond product or service usage. Responding to the suggestion of scholars (Akenji, 2014; Leonidou \& Leonidou, 2011; Sheth et al., 2011; Mont \& Plepys, 2008), this study shows that lifestyle-centric pro-environmental behaviour promotes a better understanding of the role of consumption when addressing environmental challenges. It also shows how pro-environmental behaviour adoption can be motivated across green and non-green products or services.

According to Carrington et al. (2010), situational factors act as important stimulus for individuals to participate in pro-environmental activities. The lifestyle-oriented pro-environmental behaviour examined in this study has set a good platform which is consistent with the dimensions characterised by Carrington et al. (2010), specifically (i) that the behaviour is in close proximity with the individuals' daily activities, requiring a minimal learning curve (physical surrounding and antecedent states), (ii) that individuals are highly involved in and have embedded pro-environmental behaviours within their daily roles (social surrounding and task definition), (iii) that since behaviour is part of a daily routine, there is no time lapse and the behaviour is repeated frequently (temporal perspective), and (iv) that there is lower perceived risk and uncertainty with regards to the outcome of a behaviour that is related to stronger attitude and behaviour engagement.

From the regulatory and marketers' perspectives, this study puts forward the opinion that lifestyle-centric pro-environmental behaviour provides a psychological 'lubricant', where the behaviour-situation fits and is non-intrusive to the individual's existing daily routine. The lifestyle approach possibly fosters pro-environmental behaviour participation, and so it is a plausible mechanism that can facilitate the narrowing of any psychological distance. This is achieved through the practical information gained from the daily routines (Caruana et al., 2015; van Dam \& Fischer, 2015; Carrington, Neville, \& Whitwell, 2012; Leonidou \& Leonidou, 2011; Miller et al., 2010; Powell \& Colyvas, 2008) hence, it minimises the information asymmetry issue. Furthermore, lifestyle centric pro-environment engagements are personalised, i.e. the individuals are able to relate to, and appreciate the pro-environmental activities. In that regard, they can re-calibrate the pro-environmental activities that will fit well into their values and beliefs. 


\section{Conclusion and Recommendation for Future Study}

It is evident that the self-efficacy mechanism has a significant influence on attitude. The mechanism enables individuals to orchestrate their capabilities in managing their daily activities and in coping with the dynamic environmental sustainability issues (Ajzen, 2002; Bandura, 1993; Vallacher \& Wegner, 1989). Perceived self-efficacy will reaffirm the self-determinant aspects of the individuals who are in search of solutions and the execution of strategies in dealing with prospective conditions.

Perceived self-efficacy enables individuals to preservere their proenvironmental behaviours, particularly among individuals who are highly engaged in pro-environmental behaviours (Bandura, 1982). This implies that when individuals encounter a counterintuitive environment that can possibly impede their pro-environmental behaviours, their perceived self-efficacy will be activated and these individuals will be prompted to find an alternative solution within their own capabilities and capacities to accomplish their desired behaviours.

This study has demonstrated that perceived self-efficacy makes attitude 'healthier' and resistant because it provides individuals with the supporting information and arguments needed to perform an action. Perceived self-efficacy is evidently, a potent predictor to attitude; it fortifies attitude towards pro-environmental behaviours. The finding of this study suggests that future research should examine the antecedents of perceived self-efficacy so as to enable a deeper understanding of the factors that contribute to an individual's active coping strategy.

This study is limited by the absence of a rural community which has different environmental settings, both in the public and private sphere, when compared to the urban setting. In addition, the self-reported statements of this study were based on the respondents' ability to recall past experiences of pro-environmental behaviours and not based on recent behaviours. Therefore, the retrospection of behavioural incidences could have been over-reported or under-reported unintentionally.

This study also suggests the possible presence of an intervening variable in the relationship between perceived self-efficacy and proenvironmental behaviours. The cues of the effect of self-efficacy on different levels of pro-environmental behaviours have given rise to possible self-monitoring efforts which play an important role in managing the attitude-behaviour relationship. Therefore, future research should consider investigating the contributing factors that amplify the 
state of perceived self-efficacy among lower pro-enviromental behaviour adopters by integrating self-regulatory theory insights to enrich the body of knowledge.

\section{References}

Ajzen, I. (2002). Perceived behavioral control, self-efficacy, locus of control, and the theory of planned behavior. Journal of Applied Social Psychology, 32(4), 665-683. http://dx.doi.org/10.1111/j.1559-1816.2002.tb00236.x

Akenji, L. (2014). Consumer scapegoatism and limits to green consumerism. Journal of Cleaner Production, 63(January), 13-23. http://dx.doi.org/ 10.1016/j.jclepro.2013.05.022

Bagozzi, R., \& Yi, Y. (1988). On the evaluation of structural equation models. Journal of the Academy of Marketing Science, 16(1), 74-94. http://dx.doi.org/ 10.1007/BF02723327

Baker, M.A., Davis, E.A., \& Weaver, P.A. (2014). Eco-friendly attitudes, barriers to participation, and differences in behavior at green hotels. Cornell Hospitality Quarterly, 55(1), 89-99. http://dx.doi.org/10.1177/ 1938965513504483

Bandura, A. (1991). Social cognitive theory of self-regulation. Organizational Behavior and Human Decision Processes, 50(2), 248-287. http://dx.doi. org/10.1016/0749-5978(91)90022-L

Bandura, A. (1993). Perceived self-efficacy in cognitive development and functioning. Educational Psychologist, 28(2), 117-148.

Bandura, A. (2001). Social cognitive theory: An agentic perspective. Annual Review of Psychology, 52(1), 1-26. http://dx.doi.org/10.1146/annurev. psych.52.1.1

Barr, S., Shaw, G., \& Coles, T. (2011). Times for (un)sustainability? Challenges and opportunities for developing behaviour change policy. A case-study of consumers at home and away. Global Environmental Change, 21(4), 12341244. http://dx.doi.org/10.1016/j.gloenvcha.2011.07.011

Bauer, H.H., Heinrich, D., \& Schäfer, D.B. (2013). The effects of organic labels on global, local, and private brands: More hype than substance? Journal of Business Research, 66(8), 1035-1043. http://dx.doi.org/10.1016/j.jbusres. 2011.12.028

Bhattacharyya, A., \& Cummings, L. (2014). Attitudes towards environmental responsibility within Australia and India: A comparative study. Journal of Environmental Planning and Management, 57(5), 769-791. http://dx.doi.org/ 10.1080/09640568.2013.768972

Boschetti, F., Richert, C., Walker, I., Price, J., \& Dutra, L. (2012). Assessing attitudes and cognitive styles of stakeholders in environmental projects involving computer modelling. Ecological Modelling, 247(December), 98111. http:/ / dx.doi.org/10.1016/j.ecolmodel.2012.07.027 
Breunig, M., Murtell, J., Russell, C., \& Howard, R. (2014). The impact of integrated environmental studies programs: Are students motivated to act pro-environmentally? Environmental Education Research, 20(3), 372-386. http://dx.doi.org/10.1080/13504622.2013.807326

Briceno, T., \& Stagl, S. (2006). The role of social processes for sustainable consumption. Journal of Cleaner Production, 14(17), 1541-1551. http:// dx.doi.org/ 10.1016/j.jclepro.2006.01.027

Bucic, T., Harris, J., \& Arli, D. (2012). Ethical consumers among the millennials: A cross-national study. Journal of Business Ethics, 110(1), 113-131. http:// dx.doi.org/10.1007/s10551-011-1151-z

Carrington, M.J., Neville, B.A, \& Whitwell, G.J. (2010). Why ethical consumers don't walk their talk: Towards a framework for understanding the gap between the ethical purchase intentions and actual buying behaviour of ethically minded consumers. Journal of Business Ethics, 97(1), 139-158. http://dx.doi.org/10.1007/s10551-010-0501-6

Carrington, M.J., Neville, B.A., \& Whitwell, G.J. (2012). Lost in translation: Exploring the ethical consumer intention-behavior gap. Journal of Business Research, 67(1), 2759-2767. http://dx.doi.org/10.1016/j.jbusres. 2012.09.022

Caruana, R., Carrington, M.J., \& Chatzidakis, A. (2015). Beyond the attitudebehaviour gap: Novel perspectives in consumer ethics: Introduction to the thematic symposium. Journal of Business Ethics, 136(2), 215-218. http:// dx.doi.org/10.1007/s10551-014-2444-9

Celik, V., \& Yesilyurt, E. (2013). Attitudes to technology, perceived computer self-efficacy and computer anxiety as predictors of computer supported education. Computers \& Education, 60(1), 148-158. http://dx.doi.org/ 10.1016/j.compedu.2012.06.008

Cheatham, L., \& Tormala, Z.L. (2015). Attitude certainty and attitudinal advocacy: The unique roles of clarity and correctness. Personality and Social Psychology Bulletin, 41(11), 1537-1550. http://dx.doi.org/10.1177/ 0146167215601406

Chen, A., \& Peng, N. (2012). Green hotel knowledge and tourists' staying behavior. Annals of Tourism Research, 39(4), 2211-2216. http://dx.doi. org/10.1016/j.annals.2012.07.003

Chen, X., Peterson, M.N., Hull, V., Lu, C., Lee, G.D., Hong, D., \& Liu, J. (2011). Effects of attitudinal and sociodemographic factors on pro-environmental behaviour in urban China. Environmental Conservation, 38(1), 45-52. http://dx.doi.org/10.1017/S037689291000086X

Cho, Y.-N., Thyroff, A., Rapert, M.I., Park, S.-Y., \& Lee, H.J. (2013). To be or not to be green: Exploring individualism and collectivism as antecedents of environmental behavior. Journal of Business Research, 66(8), 1052-1059. http://dx.doi.org/10.1016/j.jbusres.2012.08.020

Clary, E.G., Snyder, M., Ridge, R.D., Copeland, J., Stukas, A.A., Haugen, J., \& Miene, P. (1998). Understanding and assessing the motivations of volun- 
teers: A functional approach. Journal of Personality and Social Psychology, 74(6), 1516-1530.

Cornelissen, G., Pandelaere, M., Warlop, L., \& Dewitte, S. (2008). Positive cueing: Promoting sustainable consumer behavior by cueing common environmental behaviors as environmental. International Journal of Research in Marketing, 25(1), 46-55. http:// dx.doi.org/10.1016/j.ijresmar. 2007.06 .002

Davies, I.A., Lee, Z., \& Ahonkhai, I. (2012). Do consumers care about ethicalluxury? Journal of Business Ethics, 106(1), 37-51. http://dx.doi.org/ 10.1007/s10551-011-1071-y

Department for Business Innovation and Skills (2013). Low carbon environmental goods and services (LCEGS): Report for 2011/12. London: Crown Copyright.

Evans, D. (2011). Consuming conventions: Sustainable consumption, ecological citizenship and the worlds of worth. Journal of Rural Studies, 27(2), 109115. http://dx.doi.org/10.1016/j.jrurstud.2011.02.002

Follows, S.B., \& Jobber, D. (2000). Environmentally responsible purchase behaviour: A test of a consumer model consumer model. European Journal of Marketing, 34(5/6), 723-746. http://dx.doi.org/10.1108/ 03090560010322009

Gist, M.E. (1987). Self-efficacy: Implications for organizational behavior and human resource management. Academy of Management Review, 12(3), 472485. http://dx.doi.org/10.5465/amr.1987.4306562

Glasman, L.R., \& Albarracín, D. (2006). Forming attitudes that predict future behavior: A meta analysis of the attitude-behavior relation. Psychological Bulletin, 132(5), 778-822. http:/ / dx.doi.org/10.1037/0033-2909.132.5.778

Hair, J.F., Sarstedt, M., Ringle, C.M., \& Mena, J.A. (2012). An assessment of the use of partial least squares structural equation modeling in marketing research. Journal of the Academy of Marketing Science, 40(3), 414-433. http:/ / dx.doi.org/ 10.1007/s11747-011-0261-6

Hair, J.F.J., Black, W.C., Babin, B.J., \& Anderson, R.E. (2009). Multivariate data analysis (7th ed.). Upper Saddle River, NJ: Prentice Hall.

Hair, J.F.J., Hult, G.T.M., Ringle, C.M., \& Sarstedt, M. (2014). A primer on partial least squares structural equation modeling (PLS-SEM). Thousand Oaks, CA: SAGE Publications, Inc.

Han, H., Hsu, L.T.J., \& Lee, J.S. (2009). Empirical investigation of the roles of attitudes toward green behaviors, overall image, gender, and age in hotel customers' eco-friendly decision-making process. International Journal of Hospitality Management, 28(4), 519-528. http://dx.doi.org/10.1016/j.ijhm. 2009.02.004

Haws, K.L., Winterich, K.P., \& Naylor, R.W. (2014). Seeing the world through GREEN-tinted glasses: Green consumption values and responses to environmentally friendly products. Journal of Consumer Psychology, 24(3), 336-354. http://dx.doi.org/10.1016/j.jcps.2013.11.002

Henseler, J., Ringle, C.M., \& Sarstedt, M. (2014). A new criterion for assessing discriminant validity in variance-based structural equation modeling. 
Journal of the Academy of Marketing Science, 43(1), 115-135. http://dx.doi. org/10.1007/s11747-014-0403-8

Howe, L.C., \& Krosnick, J.A. (2017). Attitude strength. Annual Review of Psychology, 68(January), 327-351. http://dx.doi.org/10.1146/annurevpsych-122414-033600

Hullett, C., \& Boster, F. (2001). Matching messages to the values underlying value-expressive and social-adjustive attitudes: Reconciling an old theory with a contemporary measurement approach. Communication Monographs, 68(2), 133-153. http://dx.doi.org/10.1080/03637750128057

Jagers, S.C., Martinsson, J., \& Matti, S. (2014). Ecological citizenship: A driver of pro-environmental behaviour? Environmental Politics, 23(3), 434-453. http://dx.doi.org/10.1080/09644016.2013.835202

Jiang, Z. (2015). Core self-evaluation and career decision self-efficacy: A mediation model of value orientations. Personality and Individual Differences, 86(November), 450-454. http://dx.doi.org/10.1016/j.paid. 2015.07.012

Jin, C.-H. (2013a). The perspective of a revised TRAM on social capital building: The case of Facebook usage. Information \& Management, 50(4), 162-168. http://dx.doi.org/10.1016/j.im.2013.03.002

Jin, C.-H. (2013b). The role of Facebook users' self-systems in generating social relationships and social capital effects. New Media \& Society, 17(4), 501-519. http://dx.doi.org/10.1177/1461444813506977

Johnstone, M.L., \& Tan, L.P. (2015). Exploring the gap between consumers' green rhetoric and purchasing behaviour. Journal of Business Ethics, 132(2), 311-328. http://dx.doi.org/10.1007/s10551-014-2316-3

Juvan, E., \& Dolnicar, S. (2014). The attitude-behaviour gap in sustainable tourism. Annals of Tourism Research, 48(September), 76-95. http://dx.doi. org/ 10.1016/j.annals.2014.05.012

Khazanah Research Institute. (2014). The state of households. Kuala Lumpur: Author. Retrieved from https://bit.ly/2DRmJGi

Kirchherr, J., Reike, D., \& Hekkert, M. (2017). Conceptualizing the circular economy: An analysis of 114 definitions. Resources, Conservation and Recycling, 127(December), 221-232. http://dx.doi.org/10.1016/j.resconrec. 2017.09.005

Klöckner, C.A. (2013). A comprehensive model of the psychology of environmental behaviour-A meta-analysis. Global Environmental Change, 23(5), 1028-1038. http:// dx.doi.org/10.1016/j.gloenvcha.2013.05.014

Kroesen, M., Handy, S., \& Chorus, C. (2017). Do attitudes cause behavior or vice versa? An alternative conceptualization of the attitude-behavior relationship in travel behavior modeling. Transportation Research Part A: Policy and Practice, 101(July), 190-202. http:/ / dx.doi.org/10.1016/j.tra. 2017.05.013

Leonidou, C.N., \& Leonidou, L.C. (2011). Research into environmental marketing/management: A bibliographic analysis. European Journal of Marketing, 45(1/2), 68-103. http://dx.doi.org/10.1108/03090561111095603 
Lin, Y.C., \& Chang, C.C.A. (2012). Double standard: The role of environmental consciousness in green product usage. Journal of Marketing, 76(5), 125-134.

McDonagh, P., \& Prothero, A. (2014). Sustainability marketing research: Past, present and future. Journal of Marketing Management, 30(11-12), 1186-1219. http://dx.doi.org/ 10.1080/0267257X.2014.943263

Memery, J., Megicks, P., Angell, R., \& Williams, J. (2012). Understanding ethical grocery shoppers. Journal of Business Research, 65(9), 1283-1289. http:// dx.doi.org/10.1016/j.jbusres.2011.10.042

Miller, G., Rathouse, K., Scarles, C., Holmes, K., \& Tribe, J. (2010). Public understanding of sustainable tourism. Annals of Tourism Research, 37(3), 627-645. http://dx.doi.org/10.1016/j.annals.2009.12.002

Miller, J.M., \& Peterson, D.A. (2004). Theoretical and empirical implications of attitude strength. The Journal of Politics, 66(3), 847-867. http://dx.doi.org/ 10.1111/j.1468-2508.2004.00279.x

Mont, O., \& Plepys, A. (2008). Sustainable consumption progress: Should we be proud or alarmed? Journal of Cleaner Production, 16(4), 531-537. http:/ / dx.doi.org/10.1016/j.jclepro.2007.01.009

Moore, D.J., \& Homer, P.M. (2008). Self-brand connections: The role of attitude strength and autobiographical memory primes. Journal of Business Research, 61(7), 707-714. http://dx.doi.org/10.1016/j.jbusres.2007.09.002

Moraes, C., Carrigan, M., \& Szmigin, I. (2012). The coherence of inconsistencies: Attitude-behaviour gaps and new consumption communities. Journal of Marketing Management, 28(1-2), 103-128. http://dx.doi.org/10.1080/ 0267257X.2011.615482

Omran, A., Mahmood, A., Abdul Aziz, H., \& Robinson, G.M. (2009). Investigating households attitude toward recycling of solid waste in Malaysia: A case study. International Journal of Environmental Research, 3(2), 275-288. http://dx.doi.org/10.22059/ijer.2009.55

Papaoikonomou, E., Valverde, M., \& Ryan, G. (2012). Articulating the meanings of collective experiences of ethical consumption. Journal of Business Ethics, 110(1), 15-32. http://dx.doi.org/10.1007/s10551-011-1144-y

Parzefall, M.-R., \& Kuppelwieser, V.G. (2012). Understanding the antecedents, the outcomes and the mediating role of social capital: An employee perspective. Human Relations, 65(4), 447-472. http://dx.doi.org/10.1177/ 0018726711431853

Phipps, M., Ozanne, L.K., Luchs, M.G., Subrahmanyan, S., Kapitan, S., Catlin, J.R., ... \& Weaver, T. (2013). Understanding the inherent complexity of sustainable consumption: A social cognitive framework. Journal of Business Research, 66(8), 1227-1234. http://dx.doi.org/10.1016/j.jbusres.2012.08.016 Poortinga, W., Whitmarsh, L., \& Suffolk, C. (2013). The introduction of a single-use carrier bag charge in Wales: Attitude change and behavioural spillover effects. Journal of Environmental Psychology, 36(December), 240247. http://dx.doi.org/10.1016/j.jenvp.2013.09.001 
Powell, W.W., \& Colyvas, J.A. (2008). Microfoundations of institutional theory. In R. Greenwood, C. Oliver, R. Suddaby, \& K. Sahlin (Eds.), The Sage handbook of organizational institutionalism (pp. 276-298). Thousand Oaks, CA: Sage Publications.

Ramayah, T., Lee, J.W.C., \& Mohamad, O. (2010). Green product purchase intention: Some insights from a developing country. Resources, Conservation and Recycling, 54(12), 1419-1427. http://dx.doi.org/10.1016/j. resconrec.2010.06.007

Ratliff, K.A., Howell, J.L., \& Redford, L. (2017). Attitudes toward the prototypical environmentalist predict environmentally friendly behavior. Journal of Environmental Psychology, 51(August), 132-140. http://dx.doi. org/10.1016/j.jenvp.2017.03.009

Reisinger, Y., \& Mavondo, F. (2007). Structural equation modeling: Critical issues and new developments. Journal of Travel $\mathcal{E}$ Tourism Marketing, 21(4), 41-71. http://dx.doi.org/10.1300/J073v21n04_05

Rezai, G., K.T. Phuah, Mohamed, Z., \& Shamsudin, M.N. (2012). Consumers awareness and consumption intention towards green foods. African Journal of Business Management, 6(12), 4496-4503.

Roberts, J.A., \& Bacon, D.R. (1997). Exploring the subtle relationships between environmental concern and ecologically conscious consumer behavior. Journal of Business Research, 40(1), 79-89. http://dx.doi.org/10.1016/S01482963(96)00280-9

Ryan, R.M., \& Deci, E.L. (2017). Self-determination theory: Basic psychological needs in motivation, development, and wellness. New York: Guilford Publications.

Schwarzer, R., \& Jerusalem, M. (1995). Generalized Self-Efficacy scale. In J. Weinman, S. Wright, \& M. Johnston (Eds.), Measures in health psychology: A user's portfolio. Causal and control beliefs (pp. 35-37). Windsor, UK: NFERNELSON.

Secchi, D. (2009). The cognitive side of social responsibility. Journal of Business Ethics, 88(3), 565-581.

Shaw, D., McMaster, R., \& Newholm, T. (2016). Care and commitment in ethical consumption: An exploration of the 'attitude-behaviour gap'. Journal of Business Ethics, 136(2), 251-265. http://dx.doi.org/10.1007/s10551-0142442-y

Sheth, J.N., Sethia, N.K., \& Srinivas, S. (2011). Mindful consumption: A customercentric approach to sustainability. Journal of the Academy of Marketing Science, 39(1), 21-39. http://dx.doi.org/10.1007/s11747-010-0216-3

Soyez, K. (2012). How national cultural values affect pro-environmental consumer behavior. International Marketing Review, 29(6), 623-646. http:// dx.doi.org/10.1108/02651331211277973

Steinhorst, J., Klöckner, C.A., \& Matthies, E. (2015). Saving electricity - For the money or the environment? Risks of limiting pro-environmental spillover when using monetary framing. Journal of Environmental Psychology, 43(September), 125-135. http://dx.doi.org/10.1016/j.jenvp.2015.05.012 
United Nations (2015). Resolution adopted by the General Assembly on 25 September 2015. Transforming our world: The 2030 agenda for sustainable development. New York: Author.

Vallacher, R.R., \& Wegner, D.M. (1989). Levels of personal agency: Individual variation in action identification. Journal of Personality and Social Psychology, 57(4), 660-671. http://dx.doi.org/10.1037//0022-3514.57.4.660

van Dam, Y.K., \& Fischer, A.R.H. (2015). Buying green without being seen. Environment and Behavior, 47(3), 328-356. http://dx.doi.org/10.1177/ 0013916513509481

Videras, J., Owen, A.L., Conover, E., \& Wu, S. (2012). The influence of social relationships on pro-environment behaviors. Journal of Environmental Economics and Management, 63(1), 35-50. http://dx.doi.org/10.1016/j. jeem.2011.07.006

Visser, P.S., Bizer, G.Y., \& Krosnick, J.A. (2006). Exploring the latent structure of strength-related attitude attributes. Advances in Experimental Social Psychology, 38, 1-67. http://dx.doi.org/10.1016/S0065-2601(06)38001-X

Welsch, H., \& Kühling, J. (2009). Determinants of pro-environmental consumption: The role of reference groups and routine behavior. Ecological Economics, 69(1), 166-176. http://dx.doi.org/10.1016/j.ecolecon.2009.08. 009

White, K., \& Simpson, B. (2013). When do (and don't) normative appeals influence sustainable consumer behaviors? Journal of Marketing, 77(2), 78-95.

Wilcox, K., Vallen, B., Block, L., \& Fitzsimons, G.J. (2009). Vicarious goal fulfillment: When the mere presence of a healthy option leads to an ironically indulgent decision. Journal of Consumer Research, 36(3), 380-393. http://dx.doi.org/10.1086/599219

Yazdanpanah, M., \& Forouzani, M. (2015). Application of the theory of planned behaviour to predict Iranian students' intention to purchase organic food. Journal of Cleaner Production, 107(November), 342-352. http://dx.doi. org/10.1016/j.jclepro.2015.02.071

Zhang, H., \& Lei, S.L. (2012). A structural model of residents' intention to participate in ecotourism: The case of a wetland community. Tourism Management, 33(4), 916-925. http://dx.doi.org/10.1016/j.tourman.2011.09.012

Zunick, P.V, Teeny, J.D., \& Fazio, R.H. (2017). Are some attitudes more selfdefining than others? Assessing self-related attitude functions and their consequences. Personality \& Social Psychology Bulletin, 43(8), 1136-1149. http://dx.doi.org/10.1177/0146167217705121 
Appendix 1: Measurement Items

Constructs and Items
Attitude
1. I am personally committed toward preventing
environmental problems.
2. I am personally committed toward improving
environmental problems.

3. Environmental problems are not as important as many other problems facing by the world today.

4. I am concerned about environmental problems because of the potential consequences on my wealth.

5. I am concerned about environmental problems because of the potential consequences on my lifestyle.

6. I am concerned about environmental problems because of the potential consequences on my health.

7. I am concerned about environmental problems because of the potential consequences on my community.

8. I am concerned about environmental problems because of the potential consequences on the world.

Perceived Self-efficacy

1. I can practice pro-environmental activities very easily.

2. I think that my ability to adopt pro-environmental lifestyle is greater than others.

3. I am able to understand the ways of sustaining the environment and apply it effectively.

4. I can solve difficult problems if I try hard enough.

5. If someone opposes me, I can find the means and ways to get what I want.

Jin (2013a, 2013b)

Boschetti et al. (2012)

Source

. It is easy for me to stick to my aims and accomplish my goals.

7. I am confident that I could deal efficiently with unexpected events.

8. Thanks to my resourcefulness, I know how to handle unforeseen situations.

9. I can solve most problems if I invest the necessary effort.

10. I can remain calm when facing difficulties because I can rely on my coping abilities.

11. When I am confronted with a problem, I can usually find several solutions.

12. If I am in trouble, I can usually think of a solution.

13. I can usually handle whatever comes my way. 


\section{Appendix 1: (continued)}

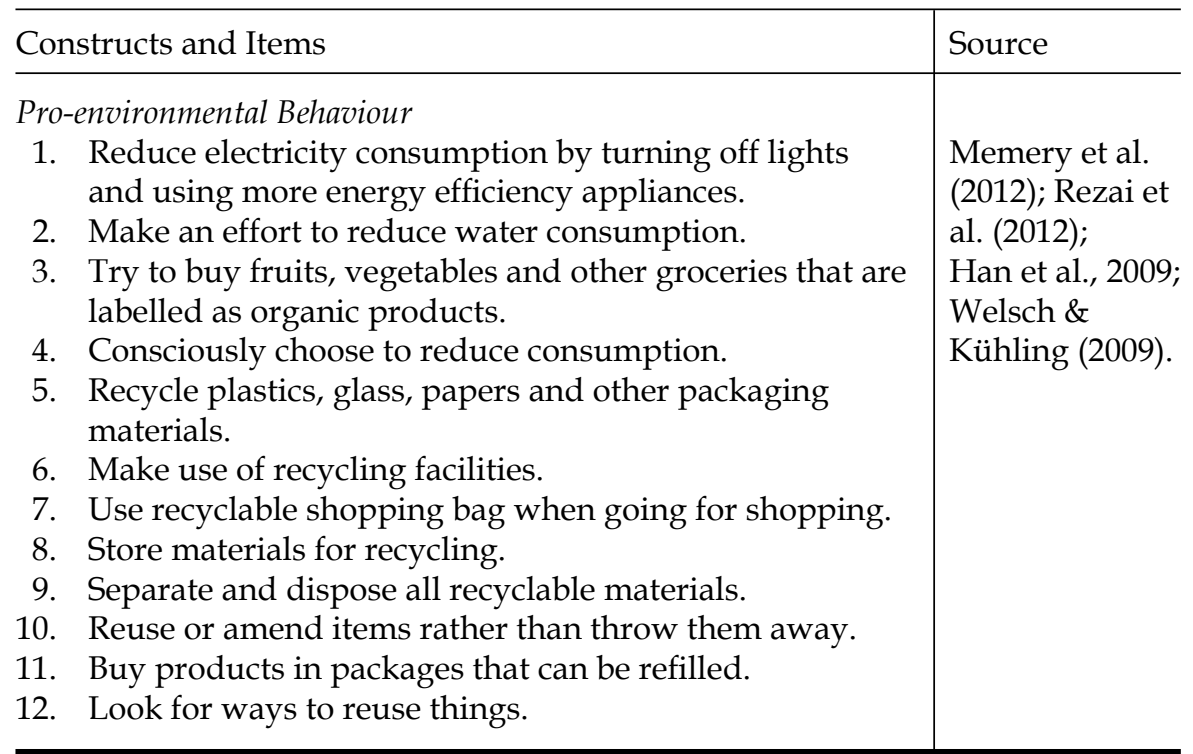

